\title{
Teachers' perceptions of interactive Islamic Prayer (iIP)
}

\author{
Dr. Mohammed Farsi \\ College of Computer Science \& Engineering at Yanbu \\ Taibah University, Saudi Arabia \\ Professor Malcolm Munro \\ School of Engineering and Computing Sciences \\ Durham University, United Kingdom
}

\begin{abstract}
This paper explores from the teachers' point of view how new interactive technology for teaching the Islamic Prayer in Primary Schools can enhance engagement and interaction in the classroom. An interesting aspect of the research in Human Computer Interaction (HCI) is that it focuses on both the human and computer perspectives. From the technological side, the focus is on how the computer hardware can improve the quality of HCI. Computer graphics for example, aims to ensure the graphics of a game is of a good standard so users will enjoy their game play, whilst operating systems are also considered in order to ensure good multiprocessing and to tune system response times to human interaction times. From the human side, $\mathrm{HCI}$ is primarily focused on the cognitive relationship with computers by ensuring the design is suitable for humans to operate successfully. The interactive Islamic Prayer (iIP) system designed for Xbox 360 Kinect with this specific goal in mind, and as an alternative to traditional learning methods. The participants for the research are Saudi Arabian primary school teachers in Jeddah, who currently teach the prayer using a traditional method. The teachers were experienced in all methods of learning (the controlled traditional method, and the iIP software) before making an informed decision on which method they prefer through a qualitative analysis of the participants teaching experiences. In addition, observations of each teaching session were organized to see how the methods engage the learners. The results show that learning by doing is extremely effective in helping the pupil' practice, interact and remember the prayer movements.
\end{abstract}

Keywords: Human-Computer Interaction, Virtual Environments, Islamic prayer, Kinesthetical learning, X-Box 360 Kinect, Learning preferences.

\section{BACKGROUND}

With the continuous improvement made in IT and computers, D'Angelo et al., (2007: 462) state that, "technology has evolved and become more central to teaching and learning". Moreover, as a result of implementing technology within classrooms, the various barriers towards effective learning may be overcome (Hannafin et al., 1997). A great deal of effort and research has been conducted in terms of assessing how well technology can provide new opportunities for learning across all levels and areas of education (Boling, 2003; Poland, La Velle and Nichol, 2003; Repenning, Rausch, Phillips and Ioannidou, 1998; Resnick, 1995, 1998; Wilensky and Stroup, 1999) (Brill and Galloway, 2007).

The Kinect and Wii consoles (Figure 1) have traditionally been designed for gaming purposes. Designers spend a great deal of time ensuring the game is designed with the user in mind (Dyck et al., 2003) User satisfaction, novelty and user performance are important for a game if it is to become commercially successful and therefore the Human Computer Interaction (HCI) features are carefully considered. Dyck et al (2003:1) further state, "games have both become 
early adopters of new HCI technologies as well as innovators in the area of HCI interaction design."

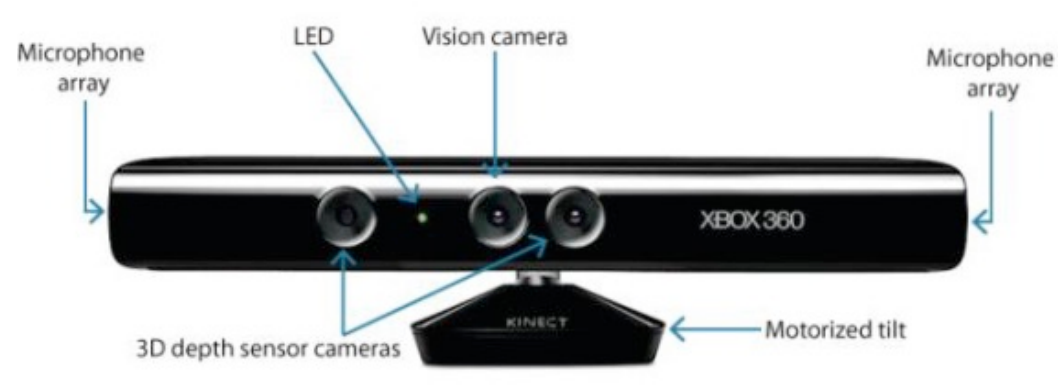

\section{KINECT}

Figure 1: XBOX Kinect 360

An interesting aspect of the research in $\mathrm{HCI}$ is that it focuses on both the human and computer perspectives. From the technological side, the focus is on how the computer hardware can improve the quality of HCI. Computer graphics for example, aims to ensure the graphics of the game is of a good standard so users will enjoy their game play, whilst operating systems are also considered in order to ensure good multiprocessing and to tune system response times to human interaction times. From the human side, HCI is primarily focused on the cognitive relationship with computers by ensuring the design is suitable for humans to operate successfully. Among the major human factors is the sensory-motor relationship, but also addressing the physiological aspects including stress (Baeker et al., 1995).

Six common learning styles from the existing literature (Figure 2) are methods for how learners can perceive information and knowledge in order to facilitate their learning. The interactive Islamic Prayer (iIP) system seeks to cater for all these styles through incorporating each style its design.

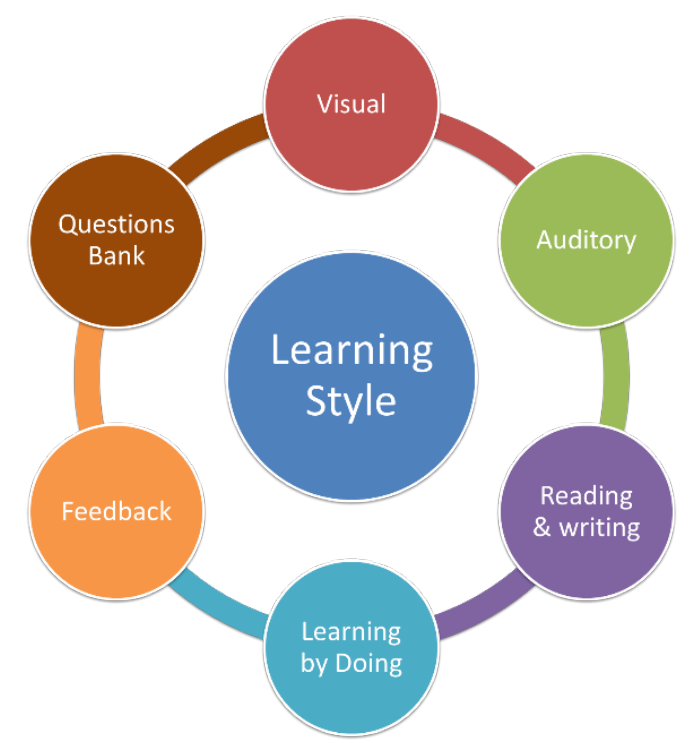

Figure 2: Six common learning styles the system provide

In designing and developing the iIP system the following hypotheses and objective were made. 


\section{Hypothesis:}

The research assumed the following:

1- The iIP system will help the pupils to engage more in the classroom and have a better learning experience

2- The iIP system will help the pupils to participate more in the classroom and with more interaction

\section{Objectives:}

The research is conducted for the following:

1- To teach users about the physical aspects of the Islamic Prayer through an interactive teaching method

2- To determine whether an interactive system through virtual environment can increase pupil's engagement and motivation in the classroom.

\section{Research Method:}

The participants for this research are Saudi Arabian primary school teachers in Jeddah, who currently teach the Islamic prayer using a traditional method. The teachers were experienced in all methods of learning (the controlled traditional method, also the iIP system) before making an informed decision on which they prefer. Questionnaires were administered before and after each teaching session. In addition, observations of each teaching session were made to see how the methods engage the learners in the classroom. The result showed that the majority of teachers were very happy to use the iIP system. It played much more of a facilitator role in controlling the pupils to ensure they all participated. It should be noted that, as the experiment took place within Saudi Arabia, the participants were all male due to specific religious and cultural restrictions.

\section{The experimental procedure:}

The steps that are taken when conducting this experiment are presented in this section (Figure 3 ). It also includes the instructions that were given to the teachers and pupils.

\section{Step 1:}

- The pupils and teachers will complete the Students' Demographic Questionnaire and Teachers' Pre Experiment Questionnaire (Document 1 and 2).

\section{Step 2:}

- The pupils are tested on their knowledge of the prayer by filling the Pre-Test form (Document 3).

- The teacher informs and instructs the class that they will learn the prayer using the iIP System; however, in order to assess ease of use, the teacher did give the pupils any indication of how it works.

- Each pupil is called up to interact and complete the prayer directly with the iIP System within 5-8 minutes, while the other pupils observed and waited for their turn.

- It should also be noted that the teacher did not give any instructions to the pupils, except for reading out what is on the screen if required.

- During the experiment the researcher observes the group for engagement and interaction and writes their note in the Observation Form (Document 4).

- The pupils are tested again for their knowledge of the prayer by filling in the Post-Test form (Document 5).

- The pupils and teacher complete the Post Questionnaire (Document 6 and 7). 


\section{Step 3:}

- The pupils and teacher are finally given the Final Questionnaire to rank preferences in specific areas for all three approaches (Prayer Book, Prayer Video, IIP System) (Document $\mathbf{8}$ and $\mathbf{9}$ ).

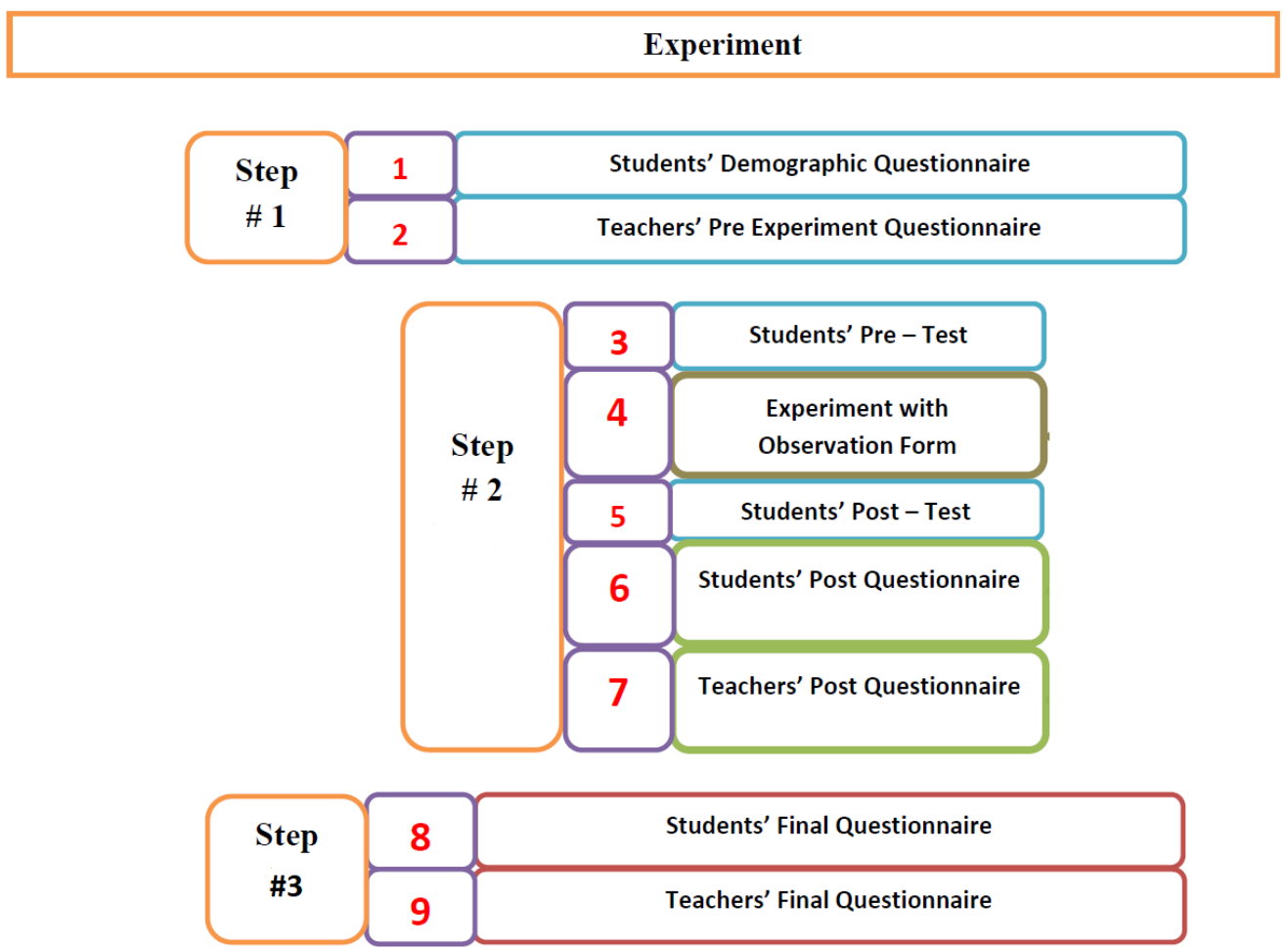

Figure 3: Chronological order and process for the data collection

The observations were used to analyse the level of interaction from the pupils within each class. This was achieved by observing how many of the pupils show a willingness to participate within the session, by recording how many times the teacher asked a question against how many and how often the learners raised their hand to answer it In addition, this included how often the pupils asked a question, which may illustrate a desire to learn. The observation also evaluated the level of engagement and interaction that the pupils showed through a number of areas pertaining to their behavior and attentiveness.

\section{THE ISLAMIC INTERACTIVE PRAYER (IIP) SYSTEM:}

The iIP System was designed and developed for the X-Box 360 Kinect, so that learners can immerse themselves into the prayer through physical interaction without the need of a controller. The goal of the system is for users to complete one unit (Rak'ah) of prayer using the interactive software, which tracks specific movements and ensures they are completing the components correctly (Figure 4) 


\section{User Interface Components}

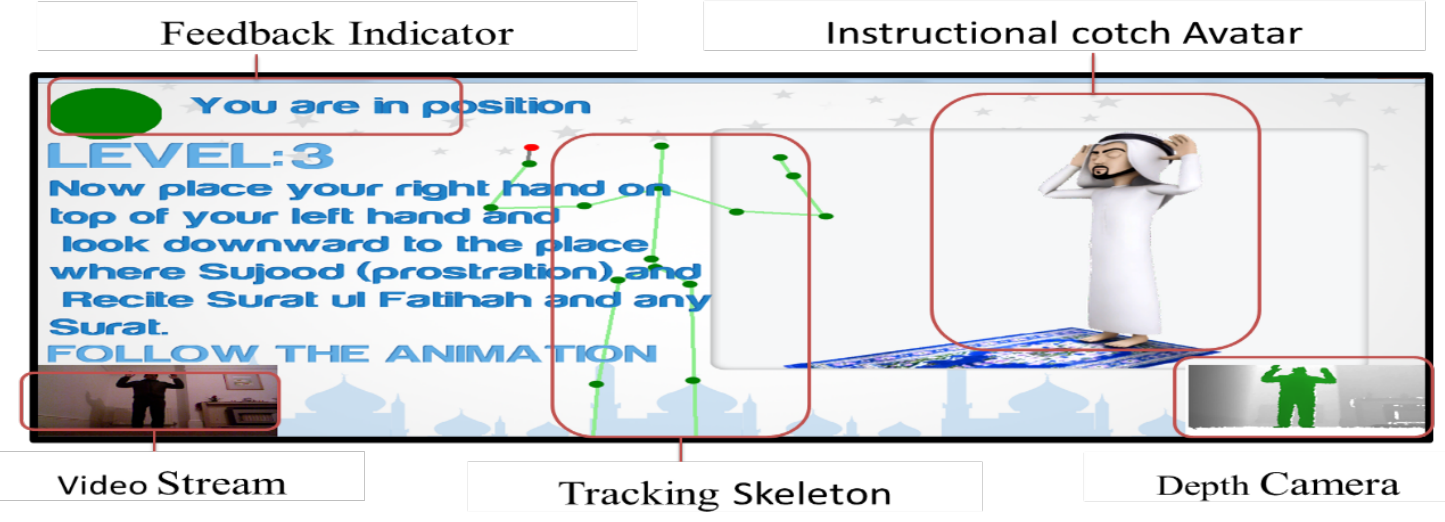

Figure 4: Main components of the GUI for the Level screens

\section{Key components of the screen}

- Instructional Coach Avatar: To aid the users in how to perform the various prayer components correctly.

- Level and Instructions: Each position has different movement to perform with different instruction.

- Video Stream: Real-time camera to help user for accurate performance.

- Tracking Skeleton: Accurately tracking the synchronous movements of the participant.

- Feedback Indicator: Red and Green indicator help participant to correct his movement.

\section{Teachers' Pre-Experiment Questionnaire}

\section{DATA ANALYSES AND RESULTS}

The teachers were given a Pre-Experiment Questionnaire (Document 2) to explore certain aspects of their teaching and their views over the "learning by doing" approach. The Questions related to the teachers' background in teaching and how long they had been teaching Islamic studies, as well as their overall Method in doing so.

All the teachers stated they had been teaching this curriculum for over five years, indicating they had the same level of experience. When asked how they would normally teach the Islamic prayer to their pupils, they provided similar answers. Whilst they all stated they predominantly adhered to the official Saudi curriculum to teach the prayer, which meant they were obliged by the school to teach the theoretical aspects from the Islamic curriculum book, two of them stated they incorporated discussion into the lesson, whilst they all stated they would try to include some level of practical examples; However, it was noted that this was seen very much as a supplementary part of the lesson due to the strict rules that stated they should follow the Book.

The next question was for teachers to explain what difficulties they found in teaching the Islamic prayer to the children. As expected, they all stated they felt restricted when teaching the lesson as they had to adhere to the Book. As a result of this, two of the teachers stated that it left very little practice or practical time for the prayer, whilst they also complained that the current method was highly theoretical and did not provide a system for the pupils to practice more at home. Lastly, one of the teachers said the difficulty he found was in getting the pupils to remember (or rather, "memorise") the names of the prayer position and the statements that are uttered during the prayer. 
The questions then moved on to whether or not the teachers incorporated software or multimedia in the classroom and explored their views on whether this could improve the learning environment. When asked if they used computers or games consoles in their teaching, they all replied that they do, particularly in using Microsoft PowerPoint slides when the need or opportunity was made available. They further explained that they used this software as it helped change the atmosphere of the class. One of them stated "Using PowerPoint makes the lesson more attractive", whilst another stated "this new generation is used to using technology in their everyday life, so it makes it more accessible and familiar to them if we also use it."

In order to assess how they felt towards the kinesthetical approach to learning (i.e. learning by doing), the teachers were asked what advantages they felt this could bring to their classroom. They all agreed that this would be a positive thing as it would improve the interaction with the pupils and help them, "not only memorise more information but it will make them more accurate when they do a particular task". They expanded upon this question when they were asked if they would find it useful to have a system that would teach the prayer by doing, and also included all the important features they require for teaching (i.e. incorporating visual and auditory aspects, facility for feedback). Again, all the teachers were unanimous in their answers, whereby they all agreed this would be an ideal answer to teaching the prayer. One teacher stated he would strongly recommend its usage as it will attract the young pupils and give them the opportunity to practice. In doing so, he stated that "using this at an early age would make the information etched into their minds". In other words, by using this type of system, the knowledge of the prayer would remain with them even when they get older. Similarly, one teacher stated that because technology is a part of our everyday life, he would recommend it as pupils are already aware of how to use it. Additionally he explained, "By using this Method, it makes the teaching more comprehensive and helps them memorise the prayer." Lastly, a teacher expanded upon his answer and said this would enable a quicker transfer of information between the learner and the teacher.

\section{Teachers' Post Questionnaire}

The teachers were given a Post Session Questionnaire (Document 7) to complete, to explore their views in relation to the iIP system. The teachers all stated that this Method was extremely effective in helping the pupils' practice, interact and remember the prayer movements. They all liked that this Method was able to cater for different learning styles, as it incorporating visual, auditory and kinesthetical aspects of learning. Moreover, the teachers could see how much the pupils were engaged with the iIP system and that this method allowed the pupils to learn from their mistakes and the mistakes of others. One teacher stated "This is probably one of the best ways I have seen on how children can learn the prayer. They are really engaged and you can see how the avatar appeals to them. You can really see the pupils feel they have achieved something when they finish the game" Another supported these views, asserting, "because the software allows them to learn by actually doing the actions. Also because there is feedback information, if they get it right or wrong, the children will remember the prayer movements more." This feedback seemed to resonate throughout all the teachers and this aspect of a more fruitful learning experience seemed to be what they felt was the iIP system's best feature.

\section{CONCLUSION}

This paper discusses the results of using the iIP system in the classroom environment. While it is clear that the use of virtual environments is predominant in the context of games, their use in education is also becoming increasingly popular. The experiment generated positive results from participants, who found the program useful in their goal of learning to pray. It was noted that the "learning by doing" approach stimulated learners' interaction and engagement, more than other approaches, and was keen on different learning styles. 


\section{References}

Baecker, R.M. ed., 2014. Readings in Human-Computer Interaction: toward the year 2000. Elsevier.

Boling, E. C. (2003), "The Transformation of Instruction Through Technology: Promoting Inclusive Learning Communities in Teacher Education Courses", Action in Teacher Education, 24 (4): 64- 73.

Brill, J.M. and Galloway, C., 2007. Perils and promises: University instructors' integration of technology in classroom-based practices. British Journal of Educational Technology, 38(1), pp.95-105.

D'Angelo, J. M. and S. A. Woosley (2007). Technology in the classroom: Friend or foe. Education. 127: $462-471$.

Dyck, J., Pinelle, D., Brown, B., Gutwin, C. (2003) Learning from games: HCI design innovations in entertainment software. In Proc. Graphics Interface 2003, pages 237-246, Halifax, Canada, 2003.

Hannafin, M., S. Land and K. Oliver (1999). Open learning environments: Foundations, methods, and models. Instructional design theories and models Volume II. C. Reigeluth, Mahway, NJ: Erlbaum. 2: 115-140.

Poland, R., La Velle, L. B. and Nichol, J. (2003), “The Virtual Field Station (VFS): Using a Virtual Reality Environment for Ecological Fieldwork in A-Level Biological Studies - Case Study 3", British Journal of Educational Technology, 34 (2): 215-231.

Repenning, A., Rausch, M., Phillips, J. and Ioannidou, A., 1998. Using Agents as a Currency of Exchange between End-Users. In WebNet.

Wilensky, U. and Stroup, W., 1999, December. Learning through participatory simulations: Network-based design for systems learning in classrooms. In Proceedings of the 1999 conference on Computer support for collaborative learning (p. 80). International Society of the Learning Sciences. 


\section{SUDENTS' PRE-DEMOGRAPHIC QUESTIONNAIRE}

Name:

Primary School Pupils

Age:

Are you a boy or a girl?

BOY

GIRL

Do you know how to pray?

YES

NO

Where did you learn how to pray?

- Parent

- Teacher

- Mosque

- Friend

- School

- Book

- Internet

- Video

- Other

Which way do you think is the best way to learn the prayer?

- Listening to your teacher/parent

- Watching a prayer video

- Reading from a prayer book

- Learning by doing

- Going to Mosque

Do you pray?

YES

If yes, how many times do you pray per day?

$\begin{array}{ll}= & \text { Once } \\ 2 \text { times } \\ = & 3 \text { times } \\ = & 4 \text { times } \\ = & 5 \text { times } \\ & \text { More than } 5 \text { times }\end{array}$

Did you enjoy praying?

YES

NO

Do you know the names for each position in the prayer?

YES

NO

\section{Thank you}


2

Name:

Sex:

How long have you been teaching Islamic studies (including the prayer)?

How do you normally teach the Islamic prayer to primary school children?

What are the difficulties in teaching the Islamic prayer to children?

Do you use computers or games consoles in your teaching?

YES

NO

If yes, as it been successful? Why or why not?

Thank you 


\section{3

In this test, choose the correct name for the prayer position in the picture

1- What is this position called?

- Ruku

- Sujood

- Qiyaam

- Takbeetul-Ihram

- Jalsa

- Taslim

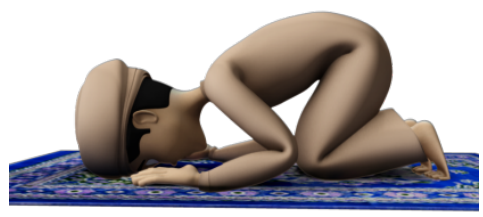

2- What is this position called?

- Ruku

- Sujood

- Qiyaam

- Takbeetul-Ihram

- Jalsa

- Taslim

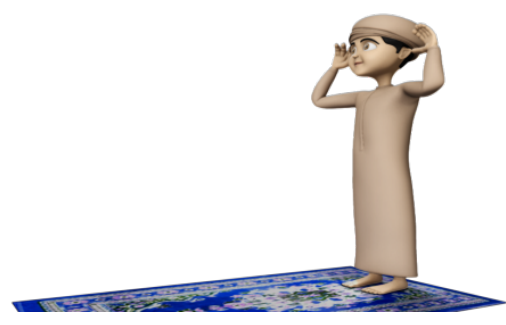

3- What is this position called?

- Ruku

- Sujood

- Qiyaam

- Takbeetul-Ihram

- Jalsa

- Taslim

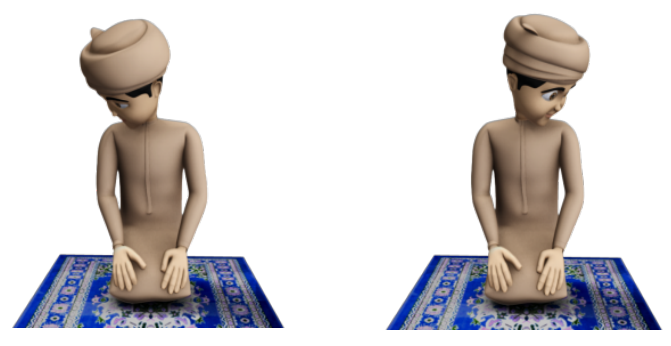

4- What is this position called?

- Ruku

- Sujood

- Qiyaam

- Takbeetul-Ihram

- Jalsa

- Taslim

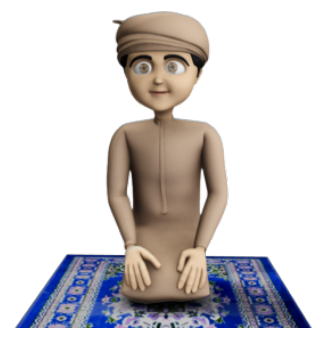

5- What is the position called?

- Ruku

- Sujood

- Qiyaam

- Takbeetul-Ihram

- Jalsa

- Taslim

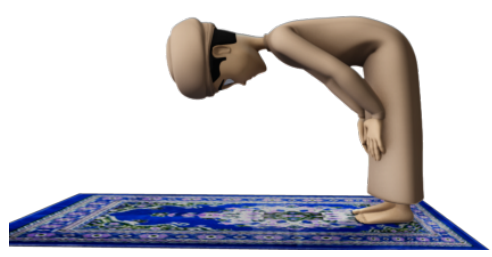


6- What should you say in Ruku?

- Subhana Rabbiyal Adhim

- Subhana Rabbiyal A'la

- Allahu Akbar

- Rabbighfir li.

- Assalamu alaikum wa rahmatullah

7- What should you say in Sujood?

- Subhana Rabbiyal Adhim

- Subhana Rabbiyal A'la

- Allahu Akbar

- Rabbighfir li.

- Assalamu alaikum wa rahmatullah

8- What should you say in Jalsa between tow Sujood?

- Subhana Rabbiyal Adhim

- Subhana Rabbiyal A'la

- Allahu Akbar

- Rabbighfir li.

- Assalamu alaikum wa rahmatullah

9- What should you say in Taslim?

- Subhana Rabbiyal Adhim

- Subhana Rabbiyal A'la

- Allahu Akbar

- Rabbighfir li.

- Assalamu alaikum wa rahmatullah

10 What should you say in Takbeetul-Ihram?

- Subhana Rabbiyal Adhim

- Subhana Rabbiyal A'la

- Allahu Akbar

- Rabbighfir li.

- Assalamu alaikum wa rahmatullah

Thank you 


\section{EXPERIMENT OBSERVATION FORM}

\section{Lesson Type:}

Day:

\section{Observing interaction during class}

(Frequency of interactions)

\begin{tabular}{|l|l|l|}
\hline Students & Raised hands to answer questions & Raised hands to ask questions. \\
\hline 1 & & \\
\hline 2 & & \\
\hline 3 & & \\
\hline 4 & & \\
\hline 5 & & \\
\hline 6 & & \\
\hline 7 & & \\
\hline 8 & & \\
\hline 9 & & \\
\hline 10 & & \\
\hline
\end{tabular}

Questions asked by teacher:

Observing engagement during class

(1= Very Bad/No action, 4= Very Good)

\begin{tabular}{|l|l|l|l|l|}
\hline Students & $\begin{array}{l}\text { Eye contact } \\
\text { with teacher }\end{array}$ & $\begin{array}{l}\text { Attentive } \\
\text { during class }\end{array}$ & $\begin{array}{l}\text { Follows } \\
\text { instructions from } \\
\text { the teacher }\end{array}$ & $\begin{array}{l}\text { Participates } \\
\text { during tasks. }\end{array}$ \\
\hline 1 & & & & \\
\hline 2 & & & & \\
\hline 3 & & & & \\
\hline 4 & & & & \\
\hline 5 & & & & \\
\hline 6 & & & & \\
\hline 7 & & & & \\
\hline 8 & & & & \\
\hline 9 & & & & \\
\hline 10 & & & & \\
\hline
\end{tabular}




\section{Observer's comments (i.e. body language, daydreaming, etc)}

\begin{tabular}{|l|l|}
\hline Student & \\
\hline 1 & \\
\hline 2 & \\
\hline 3 & \\
\hline 4 & \\
\hline 5 & \\
\hline 6 & \\
\hline 7
\end{tabular}




\section{5}

\section{STUDENTS' POST-TEST}

\section{In this test, choose the correct name for the prayer position in the picture}

1- What is this position called?

- Ruku

- Sujood

- Qiyaam

- Takbeetul-Ihram

- Jalsa

- Taslim

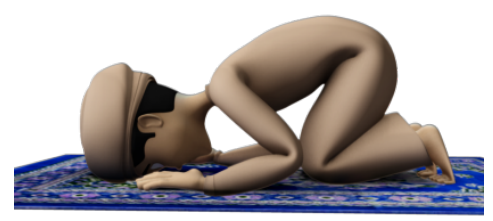

2- What is this position called?

- Ruku

- Sujood

- Qiyaam

- Takbeetul-Ihram

- Jalsa

- Taslim

3- What is this position called?

- Ruku

- Sujood

- Qiyaam

- Takbeetul-Ihram

- Jalsa

- Taslim

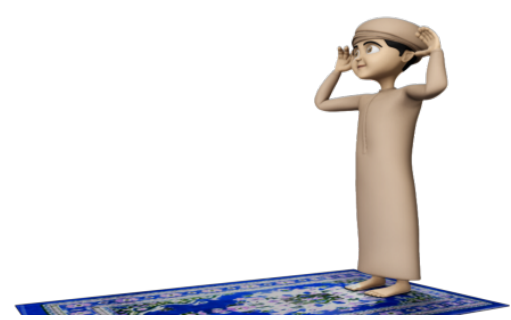

4- What is this position called?

- Ruku

- Sujood

- Qiyaam

- Takbeetul-Ihram

- Jalsa

- Taslim

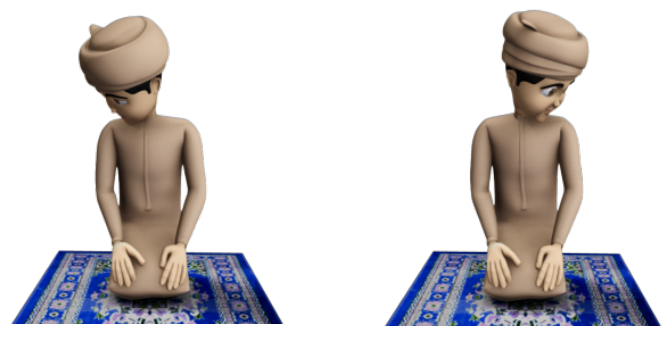

5- What is the position called?

- Ruku

- Sujood

- Qiyaam

- Takbeetul-Ihram

- Jalsa

- Taslim

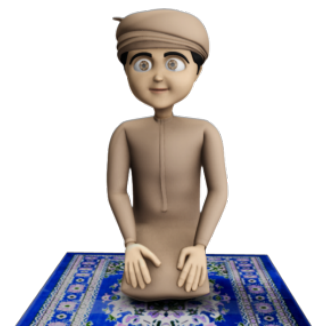


6- What should you say in Ruku?

- Subhana Rabbiyal Adhim

- Subhana Rabbiyal A'la

- Allahu Akbar

- Rabbighfir li.

- Assalamu alaikum wa rahmatullah

7- What should you say in Sujood?

- Subhana Rabbiyal Adhim

- Subhana Rabbiyal A'la

- Allahu Akbar

- Rabbighfir li.

- Assalamu alaikum wa rahmatullah

8- What should you say in Jalsa between tow Sujood?

- Subhana Rabbiyal Adhim

- Subhana Rabbiyal A'la

- Allahu Akbar

- Rabbighfir li.

- Assalamu alaikum wa rahmatullah

9- What should you say in Taslim?

- Subhana Rabbiyal Adhim

- Subhana Rabbiyal A'la

- Allahu Akbar

- Rabbighfir li.

- Assalamu alaikum wa rahmatullah

10 What should you say in Takbeetul-Ihram?

- Subhana Rabbiyal Adhim

- Subhana Rabbiyal A'la

- Allahu Akbar

- Rabbighfir li.

- Assalamu alaikum wa rahmatullah 
6 SURDENTS' POST- SESSION QUESTIONNAIRE (IIP SOFTWARE)

Primary School Pupils

\begin{tabular}{|c|c|c|c|c|c|}
\hline $\mathbf{S}$ & Statement & $\begin{array}{c}\text { Strongly } \\
\text { agree } \\
\text { (;):- }\end{array}$ & Agree & $\begin{array}{c}\text { Disagree } \\
\text { (:) }\end{array}$ & $\begin{array}{c}\text { Strongly } \\
\text { disagree } \\
\therefore \otimes\end{array}$ \\
\hline \multicolumn{6}{|c|}{ COMPREHENSION } \\
\hline S1 & The iIP makes me better understand the prayer. & & & & \\
\hline $\mathbf{S 2}$ & I know the prayer positions when using the iIP. & & & & \\
\hline S3 & I learnt a lot about the prayer using the iIP. & & & & \\
\hline \multicolumn{6}{|c|}{ Learning Experience } \\
\hline S4 & $\begin{array}{l}\text { Using the ilP Software for learning is very exciting and } \\
\text { interesting for me }\end{array}$ & & & & \\
\hline S5 & $\begin{array}{l}\text { This method makes the classroom very relaxed and } \\
\text { enjoyable }\end{array}$ & & & & \\
\hline S6 & $\begin{array}{l}\text { This method makes us want to learn to pray and use it } \\
\text { more }\end{array}$ & & & & \\
\hline \multicolumn{6}{|c|}{ Interaction } \\
\hline S7 & I found it easy to get involved in the lesson & & & & \\
\hline $\mathbf{S 8}$ & It was easy to interact with this method & & & & \\
\hline S9 & This method made me learn by practice & & & & \\
\hline \multicolumn{6}{|c|}{ Satisfaction } \\
\hline S10 & I enjoyed the lesson & & & & \\
\hline S11 & Overall, I like this method & & & & \\
\hline S12 & This Method makes me feel more confident when I pray & & & & \\
\hline \multicolumn{6}{|c|}{ Usability } \\
\hline S13 & It was easy to learn how to pray using this method & & & & \\
\hline S14 & $\begin{array}{l}\text { It was easy to follow the prayer movements using this } \\
\text { method }\end{array}$ & & & & \\
\hline S15 & $\begin{array}{l}\text { This method explains the prayer clearly from beginning } \\
\text { to end }\end{array}$ & & & & \\
\hline \multicolumn{6}{|c|}{ Achievement } \\
\hline S16 & $\begin{array}{l}\text { I can remember the prayer positions after using this } \\
\text { method }\end{array}$ & & & & \\
\hline S17 & $\begin{array}{l}\text { My prayer performance is better after using this } \\
\text { method }\end{array}$ & & & & \\
\hline
\end{tabular}

\section{Thank you}




\section{TEACHERS' POST- SESSION QUESTIONNAIRE (IIP SOFTWARE)}

Primary School Teachers

What did you like/dislike about this method?

What was the best thing about this method?

What was the worst thing about this method?

What would you improve?

Would you incorporate this method in your classroom when teaching the Islamic prayer? YES NO

Please expand on your answer (why/why not) 


\section{8}

FINAL QUESTIONNAIRE

Primary School Pupils

You have completed all three types of learning for the prayer. You have different smiley faces (1, 2 or 3$)$. Read the sentences and rank each of the types of prayer by giving them a smiley face.
$+;)$
(2):
(:)

\begin{tabular}{|l|l|l|l|l|}
\hline & & Prayer Book & Prayer Video & iIP Software \\
\hline 1 & It was very attracting and eye-catching & & & \\
\hline 2 & It helped me understand the prayer better & & & \\
\hline 3 & It made me get involved in the class & & & \\
\hline 4 & It made me interact physically & & & \\
\hline 5 & It made me very happy & & & \\
\hline
\end{tabular}

Which method do you prefer the most?
Prayer Book
- Prayer Video
iIP software

Why? 


\section{9 \\ FINAL QUESTIONNAIRE \\ Primary School Teachers}

You have experienced all three types of teaching styles for the prayer. Please rank them $\left(1^{\text {st }}, 2^{\text {nd }}\right.$ or $3^{\text {rd }}$ place) for each of the sentences below.

\begin{tabular}{|c|l|l|l|c|}
\hline & & Prayer Book & Prayer Video & $\begin{array}{c}\text { iIP } \\
\text { Software }\end{array}$ \\
\hline 1 & It was very appealing. & & & \\
\hline 2 & It helped the students to comprehend the prayer & & & \\
\hline 3 & It made the students get more involved in the class & & & \\
\hline 4 & It made the students physically interact more in the lesson. & & & \\
\hline 5 & This method makes me satisfied. & & & \\
\hline
\end{tabular}

Which method do you prefer the most?
Prayer Book
Prayer Video
iIP software

Why?

\section{Thank you}

